\title{
RADIOASTRONOMY
}

DOI $10.18524 / 1810-4215.2021 .34 .244382$

\section{OBSERVATION CONTROL DEVICE FOR THE URAN-4 DECAMETER RADIO TELESCOPE}

\author{
V.V. Galanin, V.H. Komendant, V.V. Yasinski \\ Radio Astronomy Institute of National Academy of Sciences of Ukraine, uran4@te.net.ua
}

\begin{abstract}
The URAN-4 radio telescope has been operating at the Odessa Radio Astronomy Observatory of the Radio Institute of the National Academy of Sciences of Ukraine since 1986. The telescope is an element of a decameter long-base interferometer - the radio telescopes which are located across the territory of Ukraine from west to east. The URAN-4 consists of antenna and upgraded radiometer. Antenna consists of 128-element with phased array with dimensions of $232.5 \times 22.5 \mathrm{~m}$. The telescope operates in the $10-30 \mathrm{MHz}$ range. Its receiving equipment is capable of separating two polarization components of the received signal. The radiation pattern of the radio telescope is $2,7 \times 22$ degrees at $25 \mathrm{MHz}$. The resolution of 2 seconds is realized in the interferometer mode. The instrumental complex of the radio telescope includes the upgraded device for controlling its operation. This device is made in the form of a separate unit. The ATMEL AT90S8515 microcontroller with registers and a communication circuit between the unit and the computer are mounted in it. The discrete movement in space of the antenna's directional pattern and sets the required attenuation in the attenuator during calibration are carried out with the upgraded controlling device at a given time during the observation period. The controlling device also allows adjust the current time of the computer using GPS.
\end{abstract}

Key words: microcontroller, radio telescope, antenna.

АНОТАЦІЯ. В Одеській радіоастрономічній обсерваторії РІ НАН України, починаючи з 1986 року, працює радіотелескоп УРАН-4. Інструмент $є$ елементом декаметрового довгобазового інтерферометра, радіотелескопи якого розташовані по території України із заходу на схід. Радіотелескоп складається 3128 елементної фазованої антеної решітки 3 розмірами $232,5 \times 22,5$ м та модифікованого радіометру. Інструмент працює в діапазоні 10-30 МГц, і його приймальна апаратура здатна виділяти дві поляризаційні складові сигналу. Діаграма спрямованості радіотелескопу становить на 25 МГц $3 \times 22$ градуси. У режимі інтерферометра реалізується розмір у 2 секунди. До складу апаратурного комплексу радіотелескопу входить модифікований пристрій управління роботою інструменту. Конструктивно цей пристрій виконано у вигляді окремого блоку, у якому змонтована плата 3 мікроконтролером ATMEL AT90S8515 3 регістрами управління, та схемою зв'язку блоку 3 комп'ютером. Пристрій здійснює у заданний час, у період спостережень, дискретне переміщення у просторі діаграми спрямованості антени, здійснює установку необхідного згасання у аттенюаторі під час калібрувальних вимірювань. Дозволяє так само здійснити корегування поточного часу комп'ютера за сигналами GPS, та контролює процес спостережень.

Ключові слова: мікроконтролер, радіотелескоп, антенна.

Low-frequency radio astronomy is currently being widely developed. There are many radio telescopes working in this range such as UTR-2, NenuFAR, GURT (under construction) and radio interferometers Uran and Lofar. For most low-frequency telescopes the antennas have different design such as phased antenna arrays with discrete control in space of the directional patterns. Each of these instruments is equipped with radiometers with various receiving and recording equipment and systems for controlling the operation of radio telescopes.

The URAN-4 radio telescope (Fig. 1) has been operating at the Odessa Radio Astronomy Observatory of the Radio Institute of the National Academy of Sciences of Ukraine since 1986. The telescope is an element of a decameter long-base interferometer (VLBI) - the radio telescopes which are located across the territory of Ukraine from west to east (Galanin et al., 1989). The URAN-4 consists of antenna and upgraded radiometer. Antenna consists of 128-element with phased array with dimensions of $232.5 \times 22.5 \mathrm{~m}$. The telescope operates in the $10-30 \mathrm{MHz}$ range and is capable of separating two polarization components of the received signal. The radiation pattern of the radio telescope is 2,7x22 degrees at frequency of $25 \mathrm{MHz}$. The resolution of 2 seconds is realized in the VLBI interferometer mode. The instrument's sensitivity in the band of $14 \mathrm{kHz}$ is $100 \mathrm{Jy}$ and in the interferometer mode it about $10 \mathrm{Jy}$ at the same frequency of $25 \mathrm{MHz}$.

The receiving equipment of the radio telescope consists of two sets. One of them equipped with the frequency and time standards. It is used in VLBI measurements. Another set is the upgraded radiometer which allows the radio telescope to operate in an independent mode. This radiometer operates at two frequencies of $20 \mathrm{MHz}$ and $25 \mathrm{MHz}$. At the same time, it can be used to isolate the received signal in different modes: in modulation, total, difference and semiantenna. These modes use different mathematical combinations with the signals received from the two halves of the radio telescope antenna. 


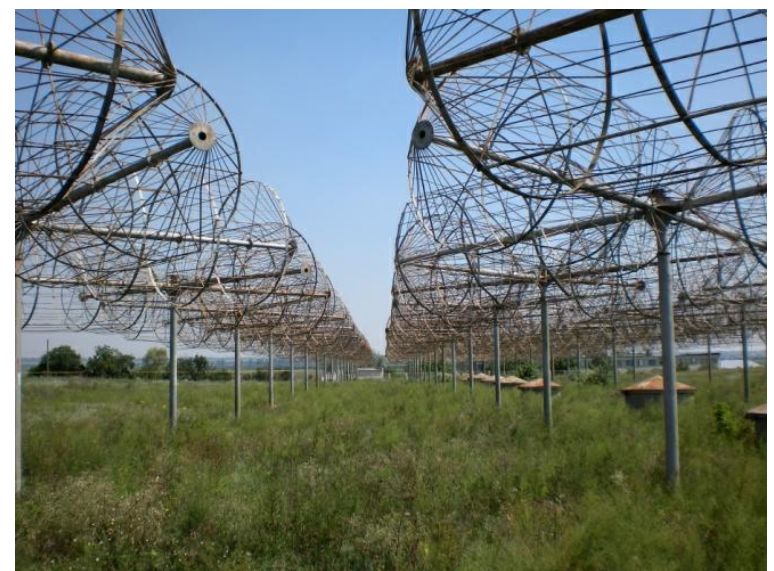

Figure 1: The URAN-4 radio telescope

Four local oscillator receivers with a bandwidth of 250 $\mathrm{kHz}$ are used as receiving devices of the radiometer. These receivers use synthesizers as local oscillators which allow them to be tuned to interference-free ranges. The incoming signals from the receiving devices are directly digitized at its inputs with a four-channel ADC. This is the feature of this radiometer. All their subsequent transformations are carried out in digital form. As a result, all digital processing of the received signal occurs in two stages. The high-frequency part is carried out in hardware. Then intermediate data packets are formed and transmitted to a computer where processing is completed in real time. The results are recorded to the $\mathrm{PC}$ hard drive and on the monitor screen.

The instrumental complex of the radio telescope also includes the upgraded device for controlling the operation of the telescope. This device is made in the form of a separate unit (Fig. 2). It contains a board with the ATMEL AT90S 8515 microcontroller with a circuit for connecting the unit with a computer and registers. They are used to control the operation of the radio telescope.

The discrete movement in space of the antenna's directional pattern are carried out with the upgraded controlling device at a given time during the observation period. It also sets the required attenuation in the attenuator during calibration measurements and allows you to correct the current computer time using GPS signals. It controls the monitoring process, recording the current working information the $\mathrm{PC}$ hard drive and displaying it on the monitor screen. Routine maintenance is carried out with its help.

The control device actions are carried out on the basis of the upcoming observation plan drawn up by the operator. This plan is entered into the computer and, according to it, the devices and processes mentioned above are controlled. The working process is carried out with developed software programs: microcontroller control program, computer time correction program and the main program which manages the entire measurement process and the recording of current operating information. This process is shown on scheme in Figure 3.

\section{Conclusion}

The device has been operating as part of the radiometer for several years. It has shown reliable and efficient operation.

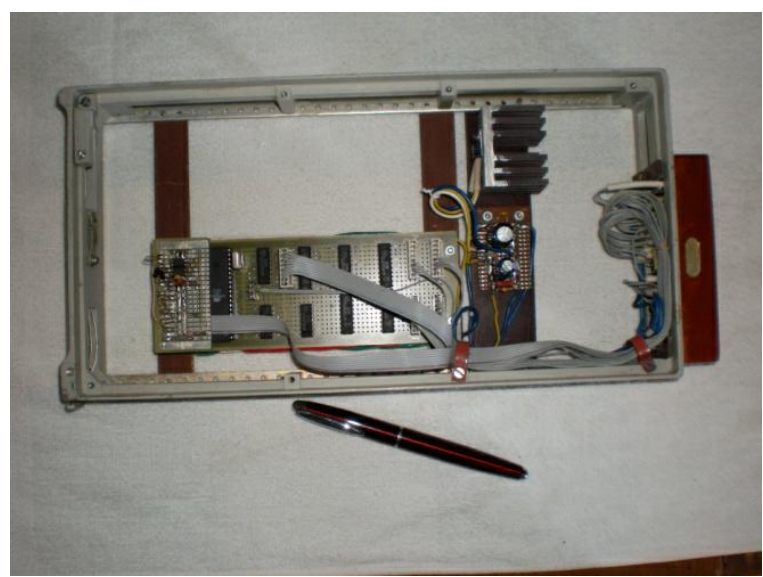

Figure 2: The upgraded device for controlling the operation of the telescope

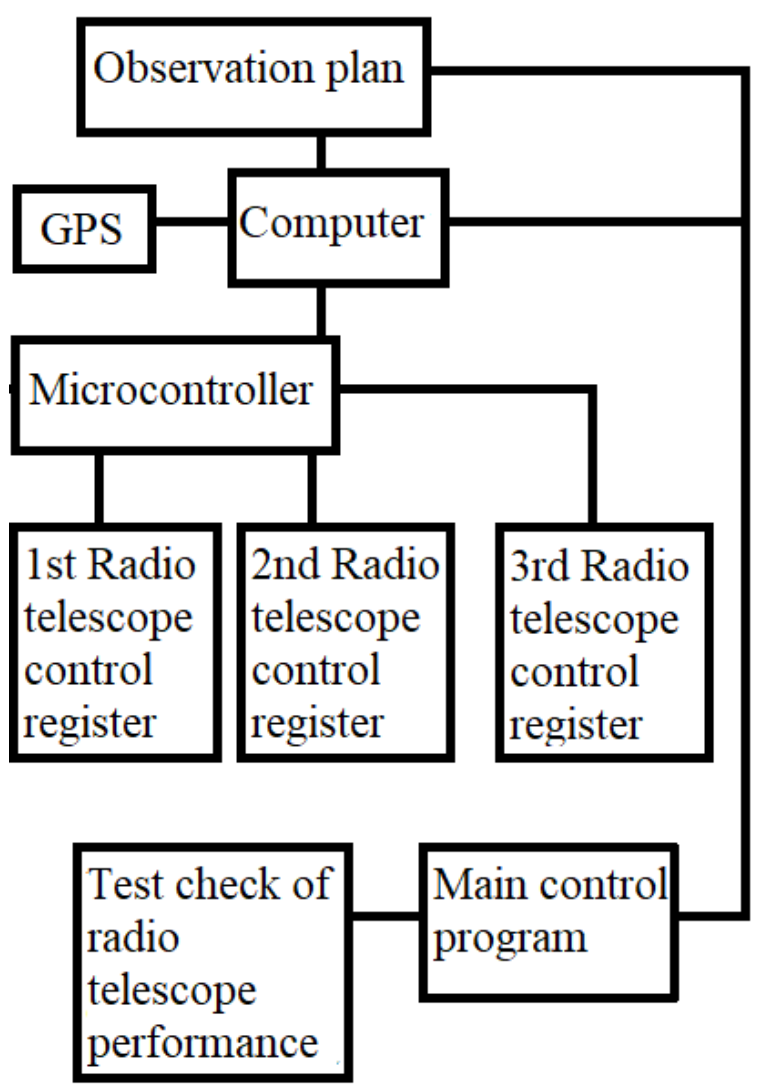

Figure 3: Scheme of the upgraded device for controlling the operation of the radio telescope: Observation plan, Computer, GPS, Microcontroller, Radio telescope control registers, Main control program, Test check of radio telescope performance.

\section{References}

Galanin V.V. et al.: 1989, Kinem. and Phys. of Cel. Bod., 5, 5, 87. 